\title{
Transformational development in a changing context: A Latin American perspective
}

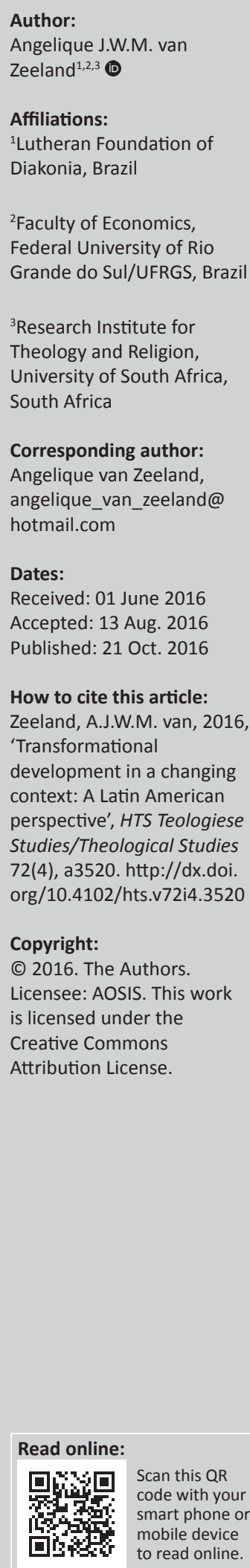

This article analyses the challenges for the strategies and practices of transformational development in a changing context. This reflection is based on contributions received during the process of dialogues and regional consultations, realised from August 2012 until March 2014, of the ACT Alliance, an international coalition of churches and faith-based organisations (FBOs) working in the areas of humanitarian response, development and advocacy. The main processes that affect the changing development context are addressed, such as the ongoing globalisation as well as the consequences, mainly regarding the shrinking space for civil society. It discusses the concepts of human development and of transformational development, based on a people-centred development vision, a human rights-based approach and advocacy, which addresses the root causes and effects of poverty, inequality and injustice. Transformational development practices, from Latin America, are presented and analysed. The article concludes that the changing development context also offers opportunities, especially regarding regional and global alliances of FBOs, civil society organisations and of social movements.

\section{Introduction}

The ongoing economic and financial crises, changing global and geopolitical trends, growing inequalities and climate change all affect the development context, prompting an international reflection regarding the meaning and practice of development. Currently the development model is grounded on expansion of consumption, economic growth and depletion of natural resources. The destructive effects of climate change adversely affect the most vulnerable people. The development model also consolidates the merging of political and economic power. In many countries policies aligned with the prevailing development model have engendered shrinking space for organised civil society and violations of human rights as well as the continued presence of poverty, hunger and deprivation.

This model of development has been questioned for several decades and new models have been proposed. Among the different actors that question the development model based on economic growth is the faith-based organisational sector. Faith-based organisations (FBOs) are organisations that are based on the core values of their faith. FBOs can be very heterogeneous and complex, making generalisations problematic. The Joint Learning Initiative on Faith and Local Communities (JLIFLC 2015:2) uses the terms 'FBOs', 'faith groups' and 'faith communities' for 'entities that are self-defined by common religiously informed profession (faith) and practice (ethics and/or worship), their leaders and congregational and community infrastructures, as well as for faithlinked healthcare providers and NGOs'. In this article the focus is on Christian FBOs under the auspices of the ACT Alliance. ACT Alliance is a coalition of 140 churches and FBOs committed to working ecumenically in the areas of humanitarian response, development and advocacy in over 100 countries. Specific reference is made to the context of Latin America and the Caribbean (LAC), where 31 FBOs, with headquarters based in the region, are active in 20 countries. Much of the work is supported by ACT members of other regions as well. The FBOs, part of the ACT Alliance, oppose proselytism and distinguish evangelism and mission, promoted by the churches, from humanitarian aid and development work, promoted by FBOs. FBOs relate in different ways to churches and consider that they are constituents of the Church, committed to working with people of all faiths. FBOs play a particular role in development. They adhere to development as a comprehensive concept, focused on a human rights-based approach; promoting people-centred development alternatives; affirming human dignity; valuing those living in poverty as agents of

Note: Angelique van Zeeland is an academic associate at the Research Institute for Theology and Religion at the University of South Africa; PhD student in Development Economics at the Faculty of Economics at the Federal University of Rio Grande do Sul/UFRGS, Brazil, programme officer of Economic Justice at the Lutheran Foundation of Diakonia, Brazil, member of the National Council of Solidarity Economy in Brazil and member of the Governing Board of the ACT Alliance.

This article forms part of the special collection on 'Engaging development: Contributions to a critical theological and religious debate' in HTS Teologiese Studies/Theological Studies Volume 72, Issue 4, 2016 
change; and pursuing environmental sustainability. Faith narratives contribute in offering an embedded language, rooted in the values of their faith, regarding human dignity. This understanding frames their human rights discourse. They advocate for transformational development, based on their spiritual values, recognising the intrinsic dignity of every life on the planet.

This article intends to address three related questions regarding the meaning and practices of development.

- What is the meaning of development as public discourse and practice and how is it affected by the ongoing economic and financial crises, changing global and geopolitical trends and climate change? The main processes that affect the changing development context will be addressed as well as the challenges for development actors, especially FBOs. Development-thinking has been influenced by the changing development context, and other development discourses have emerged. Here we will discuss human development, as opposed to the development model based on economic growth.

- How do FBOs understand development, what is their specific role in the rapidly changing world, and what does that mean for development work at different geographic levels? The concepts of rights-based development and of transformational development will be discussed. The core values of FBOs' engagement in development will also be addressed, mainly based on contributions during the process of dialogues and regional consultations of the ACT Alliance, which took place from August 2012 till March 2014, as well as contributions from FBO consultations organised by the ACT Alliance in 2014 and 2015. Two examples of how transformational development has taken shape in the Latin American context through the activities of FBOs linked to the ACT Alliance will be presented.

- Does development as discourse and practice hold an emancipatory potential and is it capable to include and to respect diversity of views, religions and alternative life concepts? Challenges for transformational development will be discussed here. Other concepts, which may broaden the discussion regarding development, will also be presented, such as solidarity economy and Buen Vivir ('well living'). Among the challenges is the question of advocacy to address and challenge power structures (political, social and economic) at different levels. Another challenge is to re-engage churches in development and to foster interreligious dialogue.

\section{Changing development context}

Development thinking and practice have been influenced substantially as a consequence of the ongoing economic crisis, altering geopolitical tendencies as well as climate change. The leading processes that modify the development context as well as the major challenges derived from it will be addressed from the perspective of FBOs engaged in development. This section is mainly based on the ACT Alliance Discussion paper 'The Changing Development
Paradigm' and the subsequent process of discussion and feedback among the members of the ACT Alliance during 2013 and 2014.

The global economic and financial crises initiated in 2008 impinged upon all world regions. In many countries an upsurge in income inequality has taken place. The crises have devastating repercussions in the daily lives of people, especially through rising unemployment and a strong increase in expenses for food as well as fees for basic services:

This also gives rise to the dimension of people's vulnerability and resilience. Managing risks and volatility is an increasingly important element of all initiatives to fight poverty as important as strengthening the voice of people living in poverty. (ACT 2013a:8)

Brazil, Russia, India, China and South-Africa, the so-called BRICS, increased their role as economic, social and political actors. They have fostered diplomatic initiatives, such as the capacity of South-South articulation in the United Nations. The South-South Cooperation (SSC) has also increased. The emerging countries have cooperated with countries in their region and with poor African countries. On the one hand the growth of SSC can lead to splintered and uncoordinated official development assistance (ODA), with little transparency. On the other hand, SSC opens up new opportunities. The International Policy Centre for Inclusive Growth of the United Nations Development Programme (UNDP-IPC-IG 2010) reinforces the promotion of South-South learning regarding technical assistance, covering fields such as food security, the fight against HIV and social policies and programmes, such as Brazil's large-scale conditional cash transfer programme Bolsa Familia (family allowance). Studies have shown that the main, targeted social transfer programmes account for a third of the recent fall in inequality.

The SSC is also growing between civil society organisations (CSOs). The social transformation that took place in Latin America during the last decade is a consequence of decades of work of CSOs in building democracy and social justice and continues to depend upon them (Manzoni \& Wolff 2011). Therefore, it is important to strengthen the SSC between CSOs, offering opportunities for mutual learning processes regarding successful development experiences.

Emerging countries have augmented their role as international actors and are considered Middle Income Countries (MICs). However, the majority of the populations of the emerging countries are still living in poverty.

Inequality is one of the main causes of extreme poverty. Some individuals and groups have consistently been excluded to access opportunities, concerning living a life that they have reason to value. Gender inequalities, as well as inequalities regarding ethnicity, are obstacles for development. In many cases inequality in income distribution is accompanied by inequality in other 'spaces', for instance different conditions of the quality of life, among others, education, health and longevity. Inequality may also 'erode social cohesion' 
(Sen 1999:93). The region of LAC is the most unequal region regarding income distribution. At the same time it is the region which presents an elevated standard of violence, crime and violations of human rights. According to the Caribbean Human Development Report presented by the United Nations Development Programme (UNDP 2012) 8.5\% of the world's population lives in this region; however, about $27 \%$ of the world's homicides are committed here.

In 2010 the Economic Commission for Latin America and the Caribbean (ECLAC), discussed an agenda for development with equality and presented the document 'Time for equality: closing gaps, opening trails'. The document highlights the importance of the inclusion of a diverse range of stakeholders among which religious associations.

In order to reverse this vicious cycle (of inequality), the support of the political and social stakeholders must be enlisted. In this connection, what is important is not only the legitimacy of the State but also the inclusion in this coalition of stakeholders that have great symbolic prestige in society and are supportive of equality, such as grassroots religious associations, philanthropic organizations, social communicators, solidarity foundations, and trade unions. (ECLAC 2010:238)

Addressing inequality is imperative for the eradication of poverty. FBOs and churches can play an important role in this regard. During the process of establishing the 2030 Agenda for Sustainable Development the ACT Alliance has played an active role, and among other involvement, has contributed through the paper: 'We all want a Future: Addressing Inequality in the Post-2015 Global Development Agenda'. The paper states that 'inequality is about power imbalances' (ACT 2012a:13). ACT recommends going beyond Gross Domestic Product (GDP) as economic growth indicator and including environmental, social and well-being indicators to measure development. Furthermore, ACT emphasises the importance of democratic and participatory governance in decision-making processes, which guarantee the engagement of the people living in poverty. In this context it is important to strengthen grassroots organisations and global alliances of social movements, such as Via Campesina ${ }^{1}$ and the Global Alliance of Waste Pickers ${ }^{2}$. FBOs can contribute in building a convergence of movements, as well as promoting global advocacy networks, with the aim of bringing international agencies and governments to account (Zeeland 2014b). FBOs can be significant actors to strengthen a transnational civil society.

In many countries policies aligned with the prevailing development model have provoked shrinking space for organised civil society and violations of human rights. Governments have enforced measures such as restrictions regarding actions of CSOs, arbitrary incarceration and assassination of human rights defenders. Practices of shrinking political space for CSOs have been documented by

1.Via Campesina is an international movement which comprises about 164 local and national organisations of peasants, landless people and indigenous people in 73 countries.

2.The Global Alliance of Waste Pickers is a networking process of waste picker's organisations from more than 30 countries. the ACT Alliance (ACT 2011). The governmental restrictions regarding the actions of CSOs threaten democracy and often result in severe violations of human rights.

The trend of declining development aid, especially regarding non-governmental organisations (NGOs), has been documented in the tenth AidWatch Report of the European NGOConfederation for Relief and Development (CONCORD). The report shows the poor performance of the EU with regard to ODA. It demonstrates that most countries did not comply with the goal to spend $0.7 \%$ of Gross National Income (GNI) as ODA in 2015. It also mentions the emerging trend to divert aid budgets from development to migration-related expenses and costs associated with hosting refugees. According to the report '[t]he refugee crisis could be used as an excuse to count noneligible expenditure relating to general migration flows as ODA' (CONCORD 2015:6). If the trend to use the development money for humanitarian purposes continues, in the long term, this may result in stagnating development in the developing countries, rising unemployment, growing poverty and hunger and as a result increase, even more, the migration flows. Development aid continues, essentially, to overcome poverty and inequality, and to promote social inclusion. It has the potential to reach the most vulnerable people and communities and is more flexible and accountable than other flows. Therefore, the report emphasises 'the importance of meeting the aid quantity target', but also 'ensuring that the aid is of high-quality' and will reach the people who live in poverty (CONCORD 2015:6-7). Furthermore, it is important to promote the development effectiveness principles as established by the Global Partnership for Effective Development Cooperation (GPEDC) and ensuring the participation of civil society.

The GPEDC was created at the Fourth High-Level Forum on Aid Effectiveness, in 2011, in Busan, Republic of Korea. New commitments were established for all donors on transparency, as well as indicators and targets through which to monitor progress (OECD 2011). The commitments made at the HighLevel Forums on Aid Effectiveness in Paris (2005), Accra (2008) and Busan (2011) regarding aid effectiveness imposed a challenge to CSOs. In 2010 CSOs assigned the Istanbul CSO Development Effectiveness Principles, shortly known as Istanbul Principles. These principles guide the work and practices of CSOs in humanitarian emergencies towards longterm development, which resulted in the Civil Society Organization Platform for Development Effectiveness and the Nairobi Declaration for Development Effectiveness in 2012. ACT Alliance, together with other FBO networks, organised, from 2013 onwards, consultations and learning processes regarding development effectiveness. This process means a shift in favour of rights-based development outcomes and development effectiveness, instead of aid delivery and aid effectiveness. It aims to qualify the development work establishing commitments to become actors for real change for people living in poverty and oppression.

The changing development context forces reflections and attitudes regarding altering consumption patterns and 
questions the prevailing development model. The ACT Alliance and the World Council of Churches (WCC) have made important contributions to these reflections. ACT affirms that economic justice is about confronting wealth and power. The statement on the Way of Just Peace affirms that:

economies of life promote careful use of resources, sustainable production and consumption, redistributive growth, workers' rights, fair taxes, fair trade, and the universal provision of clean water, clean air and other common goods. (WCC 2013:3)

This affirmation dialogues with the concept of solidarity economy, which broadens the concept of development, and will be discussed later on.

The processes that affect the changing development context lead to important interreligious challenges as well as opportunities. Religious plurality is a global phenomenon. Many societies are confronted with 'the challenge of assertion of religious identities', which express themselves 'both in the struggles for identity and justice as well as for power, politics and resources' and in certain contexts this has led to the rise of 'religious right-wing groups with militant ideologies' that unleash 'terror on those who differ' and suppress basic rights and freedom (ACT 2013a:18). The prevention of the emergence and strengthening of these groups must be based on development policy and development cooperation which aim to address its causes in order to overcome poverty, create conditions that prevent radicalisation and promote social and economic inclusion. However, most religious communities do respect diversity and establish interreligious dialogues with people from other faiths. Many local faith communities all over the world provide humanitarian assistance and are committed with social justice. FBOs and churches play an important role in supporting and strengthening the initiatives of community resilience and of regional cooperation. But this also challenges the FBOs and churches for strengthening global solidarity.

According to Phiri and Kim (2014:255) `[w]ithin the ecumenical movement, and particularly within the work of the WCC, diakonia has (...) been understood as having a broader implication for the churches' engagement with the world'. As mentioned in the document 'Theological Perspectives on Diakonia in the 21st Century' of the WCC (2012:1), in the last decade several initiatives have been developed for a 'more people-based' diakonia, to ensure the 'agency' of the people from the vulnerable communities 'in redefining diakonia in today's world'. At the same time many churches are confronted with radical changes in membership and experience a shrinking public space. In this context strengthening of interreligious dialogue and cooperation is of utmost significance to enable a more just and peaceful world.

\section{Changing development-thinking: Human development}

Development-thinking has been influenced by the changing development context, and other development discourses have emerged. Here we will discuss briefly some critics and focus especially on human development, as opposed to the development model based on economic growth.

The ongoing economic and financial crisis, the geopolitical conflicts, the growth of inequality and the environmental crisis question the foundation of the current paradigm as well as the economic logic behind it. The economic, social, environmental and institutional crisis is rooted '[...] in the failures of orthodox neoclassical economics' (Dash 2014:4). In the neoclassical economic analysis the starting point is the individual, the homo-economicus, whose human action is governed by self-interest and utility maximisation. This ontological assumption has resulted in an economic system of corporate capitalism based on greed and driven by the laws of profit maximisation and competition as well as capitalist accumulation (Dash 2014). Sen (1988) argues that the growing distance between economics and ethics has caused one of the main deficiencies of actual economic theory. Sen (1988:19) further argues that human behaviour and decision-making are based on ethical considerations and he states that ' $(t)$ he real issue is whether there is a plurality of motivations, or whether self-interest alone drives human beings' (original italics). Several theories have questioned the actual economic paradigm and proposed new concepts.

In the preface of Development as Freedom, Sen (1999) states:

We live in a world of unprecedented opulence. [...] And yet we also live in a world with remarkable deprivation, destitution and oppression. There are many new problems as well as old ones, including persistence of poverty and unfulfilled elementary needs, occurrence of famines and widespread hunger, violation of elementary political freedoms as well as of basic liberties, extensive neglect of the interests and agency of women, and worsening threats to our environment and to the sustainability of our economic and social lives. [...] Overcoming these problems is a central part of the exercise of development. (p. xi)

As illustrated in the section above on the changing development context many problems Sen refers to are still quite up-to-date. The current growth paradigm maintains or even worsens these problems, which continues the need for a development concept which aims to satisfy real human needs.

According to Sen (1988) economics has two different origins, on the one hand related to an engineering approach, and on the other hand related to ethics. The engineering approach, which forms the basis of the current mainstream economic thinking, is related to logistical issues, such as finding the appropriate means to achieve the ends. Evaluation in line with the engineering approach is often based on efficiency. The second approach related to ethics affirms that the study of economics goes far beyond the search for wealth. It covers '[...] the assessment and enhancement of more basic goals', where wealth is a tool to achieve these goals (Sen 1988:3). Sen argues that evaluation according to this approach should be based on ethics and on a more comprehensive vision of welfare and of what means living a good life. 
Sen (1988) further argues that there are generally two different attitudes towards development. The first is based on economic growth and austerity and adopts a top-down approach, where social problems will be 'resolved' through the trickling-down effect. The poor will only benefit from economic growth in a later stadium. As shown above, a huge contingent of people living in poverty never experiences the benefits of economic growth; instead, they are facing new and ever-growing social problems. The second attitude, mentioned by Sen, sees development as a process whereby social problems and attending real human needs are at the core, based on a bottom-up approach. Agency, autonomy and participation are central concepts in this approach.

The concept of development based on an engineering and top-down approach compares economic growth between countries, based on the GDP. The concept of development becomes synonymous with economic growth. In turn, the concept of human development related to ethics and based on a bottom-up approach incorporates other dimensions besides income, such as education, health and longevity, to measure the quality of life. These dimensions are considered essential to define the development of a country and of its inhabitants.

The human development approach contributes with economic evaluations as it includes informal reasoning, regarding real-world concerns, especially by way of an adequate framework for informational broadening. A farreaching example of the systematic use of informational broadening are the human development reports, which make comparisons based on observed features of living conditions. The Human Development Index (HDI) is another example of informational broadening. Economic assessments based on the evaluation of national income can accommodate little information. The HDI captures information not only on income, but also on health and education, which are important components of the actual lives of the people. Expanding the informational basis is essential to carry out assessments of public policies, social projects and programmes. The informational basis will have to address issues such as agency and welfare, besides other issues related to control, power, autonomy, rights and positive and negative freedoms (Sen 1985). Development is important in terms of increasing the effective freedom of human beings, which refers especially to autonomy. 'Development is fundamentally an empowering process' (Sen 2009:249). The human development approach offers a new way to compare and list accomplishments of development and incorporates human capabilities. It is an approach to benchmark the quality of life while also theorising about social justice and inequality. 'It ascribes an urgent task to government and public policy-namely, to improve the quality of life for all people, as defined by their capabilities' (Nussbaum 2011:19; [original italics]). This approach points to the relevance of inequality in the assessment of societies and social institutions.

The main contribution of the human development approach regarding the understanding of poverty is the broadening of the concept. According to Sen (1999:87), '[...] poverty must be seen as the deprivation of basic capabilities rather than merely as lowness of incomes, which is the standard criterion of identification of poverty'. To evaluate situations of poverty multidimensional indicators should be used, which accommodate information regarding other dimensions such as health and education, besides income. Furthermore, the human development approach widens the scope of the concept of development; it concentrates on human life, instead of the means of subsistence, and affirms the importance of the 'actual opportunities of living', to seek our goals, meaning those things that we value (Sen 2009:233). The perspective of collective action enriches the concept of human development. It incorporates activities and processes of grassroots organisations, social movements and CSOs especially regarding mobilisations to guarantee human rights and advocacy for public policies in consultative and deliberative spaces such as forums and councils. According to Evans (2002:56), '(f)ostering the expansion of such means of collective action is central to the expansion of freedom'. Human development means a people-centred development, where support for the agency of people and the expansion of their autonomy are important goals to promote social justice.

\section{FBOs' understanding of development}

This section will address the questions 'How do FBOs understand development?', 'What is their specific role in the rapidly changing world?' and 'What does that mean for development work at different geographic levels?' by discussing two concepts of development promoted by FBOs, respectively rights-based development and transformational development. Furthermore, we will discuss the core values of FBOs engaged in development and present some development practices of FBOs acting in Latin America.

To address the question 'How do FBOs understand development?' a very brief introduction will be given regarding the motivation of FBOs for acting in development, focusing on Christian FBOs. Development work implemented by FBOs and churches is part of their social ministry and in accordance with the Christian mission. From the 1960s onwards several FBOs related to the WCC, especially European FBOs currently organised in ACT Alliance Europe, were established. In this first period they often adopted a 'charitable needs-based approach', focusing on the provision of basic services directed to people living in poverty, especially in the area of education as well as primary health care (APRODEV 2012:18). Later in the 1960s and 1970s the focus was on social justice, and the WCC started to question the development model based on economic growth. From the 1970s onwards FBOs started to support ecological and family agriculture projects, and in the 1980s the 'empowerment approach' was adopted, strengthening local communities and supporting networks advocating for the rights of their members (APRODEV 2012:19). 
Currently there is a strong debate going on about whether 'development' is still the appropriate term to use. The WCC has used the notion of 'ecumenical diaconia' and 'koinonia', to express the 'ecumenical endeavour of achieving social justice, enforcing human rights and empowering individuals' (APRODEV 2012:19). In turn, the Lutheran World Federation (LWF) has used the term 'diakonia' and 'transformational diakonia' affirming that:

Transformation engages and changes all who are part of it. In that manner, transformational diakonia helps to overcome so-called helpers' syndromes, practices and relations that separate 'we' from 'they'. In the end, no person escapes vulnerability. We all need to be transformed, reconciled and empowered. [...] Transformation is clearly a process, but at the same time, transformation envisions the achievement of certain goals, arriving at a new situation where human dignity is more respected with peace and justice for more people. Thus, transformation is closely related to what also may be defined as social change, progress or development. (Nordstokke 2009:43-44)

The Ecumenical Conversations held during the 10th Assembly of the WCC in Busan in 2013, especially regarding the theme 'Compelled to Serve: Diakonia and Development in a Rapidly Changing World', concluded that a demand exists for 'a terminology that is appropriate in the sense that it expresses the distinct nature of these actors, as a distinct type of faith-based organization, and at the same time expresses the distinctiveness of their action' (Nordstokke 2014:271).

However, these terms, 'ecumenical diaconia', 'koinonia', 'diakonia' and 'transformational diakonia', are difficult to use and to be understood in a secularised development context, and most FBOs continue to use the term 'development'. Therefore, it is important to discuss the meaning of development for FBOs. Below the rights-based development concept will be discussed. The ACT Alliance during the process of dialogues and regional consultations, in the period from 2012 till 2014, discussed the growth paradigm and the question 'Is there an answer to the beyond growth paradigm?' as well as the need for reflection regarding concepts of life and broadening the dialogue in relation to the development paradigm. The final document of the Regional Consultation in LAC stated the importance to re-signify the discussion on the development paradigm by the concept of Buen Vivir ('well living') adopted by indigenous communities in Latin America. This point will be discussed further. During the above-mentioned process the members of the ACT Alliance affirmed the ACT's understanding of transformational development, which will be presented afterwards.

\section{Rights-based development from a faith-based perspective}

The rights-based development concept shares several aspects of the human development concept; both concepts are based on the interface of rights and ethics, are people-centred and value development as an empowering process. The rightsbased approach goes beyond mere addressing the current urgent need and holds governments accountable, through advocacy and through national and international law. The
Eighth Assembly of the WCC in 1998, which coincided with the 50th anniversary of the adoption of the Universal Declaration of Human Rights, stated the importance of the churches and FBOs to work for universal respect and for the implementation of human rights. According to APRODEV (2008:8) 'development and human rights work are understood to be two important components of the justice work of the churches'. In the rights-based approach to development, programmes and policies aim the realisation of human rights according to the Universal Declaration of Human Rights. Another important aspect is the promotion of capacitybuilding processes for 'duty-bearers' to meet their obligations and/or for 'rights-holders' to claim their rights.

The rights-based strategies are important for 'strengthening empowerment and advocacy work' (APRODEV 2008:6). This approach strengthens the capacities of local development partners; however, this demands a strong commitment of the partners in the North-South development cooperation with regard to self-empowering learning processes and local ownership as well as with regard to practices that challenge unequal power relations that underlie poverty. The APRODEV (2008:12) document 'Rights-based development from a faith-based perspective' outlines six principles of a rights-based approach to development: (1) a focus on structural and rootcauses; (2) equality and non-discrimination; (3) empowerment; (4) participation; (5) accountability; and (6) a focus on community and the inter-relatedness of human beings. Furthermore, the rights-based development approach demands strong alliances, between international institutions and community-based organisations, to strengthen advocacy actions. The church and faith-based platforms play an important role with regard to joint advocacy strategies and to promote human dignity. For FBOs the adoption of a rightsbased approach means that alongside the human rights discourse, reference is made to religious identities. Religion plays an important role in society; it can be not only part of the problem, but also part of the solution. According to APRODEV (2012:24) FBOs can enhance the positive role of religion in development and 'in improving the livelihoods of people'.

\section{Concept and values of transformational development}

The document 'Our Understanding of Development' affirms ACT Alliance's understanding of transformational development (ACT 2013b). The concept dialogues with the human development concept and is closely related to the rights-based development concept. The concept of transformational development is based on the Christian values of human dignity and social justice and aims to achieve positive and sustainable change in the lives of people oppressed by poverty and injustice. According to the document 'Our Understanding of Development':

transformational development draws from its theological affirmation that all persons are created in the image of God with the right and potential to live just, humane and dignified lives in sustainable communities. Profession of faith requires the 
rejection of those conditions, structures and systems which perpetuate poverty, injustice, the abuse of human rights and the destruction of the environment. (ACT 2013b:2)

In the ACT Alliance's understanding 12 concepts are further central to the idea and practice of transformational development (ACT 2013b:2-5):

- Participation recognises the right to self-determination of people living in poverty in the whole process of transformational development.

- Empowerment of people and communities can cause structural changes in power relations to achieve their rights. Coordinated autonomy of people of the same community can lead to significant social change, improving their actual and future well-being.

- Capacity development reinforces the capacities of people, and their grassroots organisations, to be able to transform situations of injustice and poverty.

- Non-discrimination on any basis including ethnicity, gender, culture, religion, political affiliation, sexual identity and age affirms the international principles like the Universal Declaration of Human Rights.

- Gender equity is a fundamental and transversal criterion for all the dimensions of the development process; it demands participation of women and men in decision-making processes and promotes gender justice relations.

- Cultural and spiritual sensitivity and the recognition of these dimensions are essential in the development process as well as an intercultural and interreligious approach.

- Reaffirming human rights by adopting a rights-based approach leads to the strengthening of civil society to advocate for the accountability of governments to promote effective political, social, economic, cultural and environmental rights.

- Advocacy pursues addressing the main causes and effects of human rights violations and poverty, starting at the grassroots levels and linking up at national and international levels through coalitions and alliances.

- Promoting peace, reconciliation and right relationships, incorporating effective prevention and reconciliation strategies pertinent to the context are essential in societies affected by conflict.

- Effective communication starts with attention and consideration for the voices of the people living in poverty. The promotion of the democratisation of communication is an important strategy to give voice to the people and communities whose rights have been violated.

- Environmental sustainability in the actions of transformational development seeks to protect God's creation for future generations. The preservation of nature and of the biodiversity should be based on local and indigenous knowledge and practices.

- Commitment to the sharing of resources seeks to avoid waste and over-consumption and promotes sensitisation and change of attitudes as well as adoption of practices of solidarity economy and fair trade.
The concept of transformational development emphasises the rights-based approach, cultural and spiritual sensitivity and human dignity as central values. It also affirms the distinct nature of FBOs under the auspices of the ACT Alliance, as well as the distinctiveness of their actions.

During the process of dialogues and regional consultations of the ACT Alliance, which took place from August 2012 until March 2014, the members of the ACT Alliance affirmed ACT's understanding of transformational development. The process demonstrated that the ACT members do promote people-centered development alternatives. They also re-affirmed their identity as FBOs guided by Christian values. Among the values that have been highlighted by the members were: human dignity and putting people first, with priority for those most oppressed and lacking opportunities; justice and equity, including the right use of power and understanding justice as a relational concept, which includes the obligation of communities; collaboration, togetherness and dialogue; and stewardship of and care for creation, including the global commons and promoting sustainability (ACT 2013a; Zeeland 2014b).

The process showed not only regional diversity among the members, but also a common understanding regarding values, principles, issues and ways of working. The members highlighted the principles of overcoming inequality and poverty and promoting social justice as well as fair distribution of wealth and resources, including condemning greed, and equal opportunity. The principle of cooperation between equals, based on mutual responsibility as a mechanism for social change globally, was also emphasised. Furthermore, the principle of transparency and accountability was mentioned, meaning upholding honesty, integrity and quality of work (ACT 2013a; Zeeland 2014b).

The distinct nature of FBOs, based on the core values of their faith and the centrality of human dignity, resulted in April 2015, in an initiative of over 40 global religious and FBO leaders to sign and launch the statement titled 'Ending Extreme Poverty: A Moral and Spiritual Imperative'. The statement was drafted by a diverse group of FBOs and religious leaders, amongst whom the ACT Alliance, who draw upon the shared moral commitments and spiritual values that unite their respective faith traditions to eliminate extreme poverty by 2030 . The statement refers to the common values of 'restoring right relationships among people, affirming human dignity, and [...] holistic development of all people'. The statement further mentions the shared convictions 'to empower and uplift - not denigrate - those living in poverty, so that they can become agents of their own transformation'. The statement also reinforces the need to tackle the underlying causes of extreme poverty, combating inequality and mitigating climate change, by holding all levels of leaderships accountable. The statement concludes by emphasising the holistic approach 'rooted in the spiritual visions of our respective faiths, and built on a shared recognition of the intrinsic dignity and value of every life on 
Earth' (Statement on Ending Extreme Poverty 2015). The religious and FBO leaders are now at the stage of translating the statement into concrete action and collaboration on global, national and local levels through a faith-based action framework to end extreme poverty.

In the prevailing development context, which shows a rise of violent conflicts, huge human displacements and migration flows, FBOs can play a specific role for peace building, reconciliation and humanitarian aid. In this rapidly changing context the 'development of (inter)national network linkages and the creation of a new common and shared identity are considered as vital components for peacebuilding and reconciliation' (Ruben 2011:231). Ostrom (2010) highlights trust as a structural factor affecting the likelihood of increased cooperation as well as its central role in coping with social dilemmas. FBOs can assume a leading role in the process of creating trust to overcome conflicts at different levels. Ruben (2011:232) considers 'different attributes of religion in the development process' and distinguishes different types of networks. The long-term relations between FBOs and grassroots organisations with regard to access of communities to basic services have established a strong identification and relation of trust between them. FBOs and councils of churches play an important role, at regional and national levels, regarding advocacy, claiming participation in decisionmaking processes and for the protection of human rights. These attributes, a relation of trust and protection of human rights, in post-conflict situations, with distrust in state institutions, open up possibilities for FBOs to play a distinctive role in the process of reconciliation. In times of disasters, communities often rely on faith communities for their coping strategy. In conflict situations, local faith leaders and faith groups play an important role. 'Local faith communities have the ability to leverage considerable resources in humanitarian response, including social capital, human resources, spiritual resilience, facilities, and financial support' (ACT 2015:2). In humanitarian contexts, FBOs can support local faith institutions, 'facilitating rapid response to disaster and reinforcing resilience of local communities for peace building and recovery' (ACT 2015:2). FBOs and faith communities can contribute, especially in multireligious contexts, through their values of human dignity, and the meaning of faith in shaping the human rights discourse, in offering assistance, comfort, hope and compassion.

The values emphasised in the statement signed by religious and FBO leaders dialogue with the values which came up in the process of regional consultations of the ACT Alliance, as well as with the values highlighted in the process of reconciliation and peace building. The relationship of trust established through the long-term engagement of FBOs with the local grassroots organisations is an important feature and emphasises the distinctive role of FBOs in the development process as well as in humanitarian aid. Special emphasis can be placed on the values of human dignity and the empowerment of those living in poverty to become agents of transformation, as well as the need to act and advocate regarding overcoming inequality.

\section{Practices of transformational development in Latin America}

To illustrate the range of transformational development two examples from Latin America are presented. The first example deals with the support for grassroots organisations through programmes and funds for small projects operated by national FBOs with support of international FBOs, who are all members of the ACT Alliance. These programmes have a diaconal focus, starting with the support of projects of people living in poverty and promoting the strengthening of grassroots organisations. A case study was undertaken in 2012 and 2013 among four FBOs in Argentina, Brazil and Peru. The main focus was on projects related to the solidarity economy. The study affirmed that the methodology of supporting subsequent small projects established a relationship of trust between the FBOs and the grassroots organisations, which often resulted in the strengthening of the autonomy and agency of the communities (Reetz 2013). Several projects gained the recognition of local authorities and became references for public policies (Zeeland 2014a).

This process can be demonstrated by the subsequent support for the National Movement of Waste Pickers (MNCR) founded in 2001 in Brazil. The first support was for local community groups of waste pickers to improve their situation. Thereafter support was directed towards the mobilisation of waste pickers and capacity-building processes to empower the waste pickers, which resulted in a strong movement with capacity to participate in deliberative processes regarding the formulation of public policies, such as the approval of the National Solid Waste Policy in 2010. In the same year the waste pickers' cooperative COOTRACAR signed a contract with the municipality for the selective collection of urban solid waste. Through this contract it was possible to include a huge number of informal waste pickers. But the situation altered after a political change in the municipality, which resulted in uncertainty with regard to the payment of the service as well as to the continuation of the contract, which in turn resulted in unstable income for the waste pickers and diminished the membership of the cooperative. As a strategy for diversification of income, the cooperative provided partnerships with schools, community institutions and supermarkets. Through strategies of resistance and collective action the cooperative managed to renegotiate the contract (Zeeland 2014c). The case exposes the vulnerability of the waste pickers' cooperative and emphasises the relevance of collective action. It shows the importance of capacity-building processes and empowerment of the people living in poverty to become agents of change. Effective public policies, which change the structures of oppression, depend on advocacy networks and incidence in public policies, involving grassroots organisations, social movements and FBOs, committed to a process of social transformation.

3.COOTRACAR is an organisation of waste pickers in Gravatai in the south of Brazil which started in 1996 as an association and turned into a cooperative in 2009; currently, it is composed of 55 waste pickers. 
Another example of transformational development is the support for quilombola communities. The quilombos appeared during the Black slavery regime, which prevailed in Brazil for 300 years, as a resistance strategy, which continued after the abolition of slavery in 1888 . They were ignored by the Brazilian State and were invisible to society. Only after 100 years, at the promulgation of Federal Constitution in 1988, the quilombos and the right to ownership of their lands were recognised. However, only $6 \%$ of the quilombos have achieved the regulation of their territories (Dutra 2011). They live in situations of socio-economic inequality and violation of their rights and are among the most vulnerable groups regarding food insecurity (Brazil 2007). Against the above backdrop an impact study was conducted by five ACT Alliance organisations, three national FBOs and two international FBOs in 2011. The aim was to assess the impact of the support to the quilombola movement in the period between 1996 and 2009. The study was conducted in five quilombola communities in several regions of Brazil. The main impacts were regarding the following issues, assertion of identity and confrontation of racism; right to land; organisation of the quilombola movement; advocacy and influence on public policy; and access to services and improvements in quality of life.

With regard to confrontation of racism, the study affirmed that 'quilombola communities and movements benefit from enhanced self-determination and connections with anti-racist social movements and Black movements' (Dutra 2011:108). In relation to the right to land, progress in the numbers of entitlements is minimal, showing the complex struggle for rights. 'Denying the quilombola communities their right to land and territory generates a movement towards their expulsion, impoverishment and dependency' (Dutra 2011:127). The study affirmed that the organisation of the quilombola movement made good progress towards establishing 'efficient community and local organizations that are considered national standard-bearers, overcoming forced isolation and institutional racism' (Dutra 2011:115). Other findings of the study refer to the progress in access to service and improvements in quality of life. Quilombola communities in the south of Brazil have access to national food security programmes, but instead of 'receiving basic food baskets from the Zero Hunger Program, they supply products for government distribution to schools, crèches, hospitals' (Dutra 2011:121). Nutrition and health have also improved 'with the introduction of healthier food and the recovery of knowledge about traditional remedies' (Dutra 2011:121).

In conclusion it could be said that the study contributed to demonstrate the added value of ecumenical cooperation. This cooperation led to the establishment of relationships of mutual learning and trust, advocacy and influence on public policies and fostering of intercultural and interreligious dialogues, which resulted in reducing religious intolerance towards Afro-Brazilian religions. The study concluded that 'the visibility of quilombola communities has increased both through and within the ecumenical family, which helps to reduce the stigma and isolation of structural racism'
(Dutra 2011:118). The FBOs also extended the struggles and demands of the quilombos towards national and international CSOs as well as churches.

\section{Prevailing challenges for transformational development}

This last section addresses the question 'Does development as discourse and practice hold emancipatory potential and is it capable to include and to respect diversity of views, religions and alternative life concepts?' Challenges for FBOs engaged in transformational development will also be discussed.

As mentioned in the sections before, very different concepts of development are in use. For mainstream economics and for most governments development is equal to economic growth and based on increased production and consumption and indiscriminate extraction of natural resources. This model however results in rising economic and social inequality, violations of human rights and destruction of nature and biodiversity. The concept of human development considers other dimensions besides income, such as education, health and longevity, which are essential to define the development of a country and its inhabitants. The FBOs under the auspices of the ACT Alliance have adopted the rights-based development concept, which shares several aspects of human development; both are people-centred and value development as an empowering process. The ACT Alliance understanding of development is based on the Christian values of human dignity and social justice and incorporates the right-based approach. The changing development context reinforces the need for rethinking the development concept. The model based on economic growth has led to huge economic and social crises on a global scale, and this urges the need that other concepts of development, such as human development and transformational development gain space in the international context. For now these concepts define mostly the engagement in development of CSOs and FBOs. Therefore, there is a need to strengthen advocacy strategies towards governments and global agencies. This need reinforces the importance of continuity of the ACT Alliance as well as of other FBOs in the process of implementation of the 2030 Agenda for Sustainable Development. Participation in regional and global networks and platforms is important to contribute to the development process and ensure that shifts are going in the right direction.

As mentioned before, many churches are facing membership which is radically changing and the public space of the churches is gradually shrinking. Many churches have become inward looking concerned with their own problems, which challenge the churches to re-engage as actors in development and to foster intercultural and interreligious dialogue.

The engagement of FBOs in development is based on their spiritual values. As mentioned earlier in this article, the statement 'Ending Extreme Poverty: A Moral and Spiritual Imperative' was endorsed by over 40 global religious and 
FBO leaders, as diverse as, American Jewish World Service, Buddhist Global Relief, Catholic Relief Services, Islamic Relief International and WCC, which shows the potential of a development discourse capable of including a diversity of views and religions. The statement affirms a holistic development approach which recognises the intrinsic dignity of every life on the Earth and empowers those living in poverty to become agents of change, therefore holding an emancipatory potential. The challenge is now to translate the statement into concrete action and collaboration. The operationalisation of the statement as well as of the concept of transformational development constitutes a challenge for FBOs.

With regard to the issue to broaden the discussion on the development paradigm and include alternative life concepts, the ACT Alliance regional consultations have made a contribution. The final document of the Regional Consultation in LAC states:

In this context, we consider important to broaden the discussion on the development paradigm, as we face a crisis of the Way of Life, not only re-signifying it but also re-locating it, based on the knowledge, experiences and practices from Latin America and the Caribbean, such as the concept of Buen Vivir (well living), which comes from our ancestral knowledge and advocates for a full and sustainable life for social and natural beings, restores harmony and mutual respect, overcomes poverty and injustice and incorporates an intercultural approach. (ACT 2012b:3)

The ACT members of LAC are now in the process of formulating the strategic plan for the region. One of the aims is to support the experiences and capabilities of the indigenous peoples, peasants and other actors on ways of coexistence with nature, recovering their ancestral knowledge, regarding care of creation and 'Buen Vivir' (living well), expressed through their relations, spirituality and holistic Cosmo vision.

Another concept that broadens the discussion regarding development is solidarity economy. Solidarity economy initiatives appear to address poverty and cover a wide range of economic experiences in areas such as production, service delivery and trade. According to Razeto (1993) these initiatives are based on a specific rationality which highlights aspects such as democratic management and co-operation. Singer (2000) emphasises the struggle against capitalism to change unjust and exploitative economic relations. Solidarity economy as alternative economic organisation intends to satisfy human needs and is constituted of elements such as participatory decision-making and social cohesion. Amin (2009) highlights the capacity of solidarity economy to mobilise local resources and capabilities through popular mobilisation with the aim to meet local and social needs as well as human development. One of the central characteristics of solidarity economy is related to collective organisation. During the process of regional consultations and discussions regarding the changing development context, the ACT members of South America identified the solidarity economy as an alternative to the beyond growth paradigm. They reinforced the need to promote solidarity initiatives, based on the perspective of cooperation, solidarity and reciprocity, promoting environmental and planetary sustainability and social and cultural diversity, as well as encouraging conscious and sustainable consumption patterns.

The growing inequality in countries and between countries is affirmed by FBOs as one of the main causes of poverty and exclusion. This issue raises the question of how to address and challenge power structures (political, social and economic) at different levels. The strength of networks of FBOs, like the ACT Alliance, is being present at the grassroots level as well as at different policy levels and therefore has an important advocacy role. It is equally important to strengthen the role of grassroots organisations and social movements in advocacy processes on behalf of social justice. FBOs have a role to play to contribute to building a convergence of movements and to promote the internationalisation of the causes.

One theme for further reflection is how FBOs engage together in the field of development. This issue is raised by different actors, such as the WCC and ACT Alliance. The general secretary of the WCC, Dr Olav Fykse Tveit, raises the questions:

How can we now focus more on what we do together to make a difference together? How can we focus more on where we are going, more than discussing only where we are in relation to one another as institutions? (Nordstokke 2014:272)

This issue was also raised at the General Assembly of the ACT Alliance realised in 2014. This process will, among other questions, address the challenge of cooperation between equals, based on mutual responsibility as a mechanism for social change globally, which demands further reflection regarding the understanding of genuine partnership and the configuration of this ecumenical partnership constituted of mutual learning and mutual responsibilities.

The reflections of the WCC and LWF whether 'development' is still the appropriate term to use, and the notions of 'ecumenical diaconia', 'koinonia' and 'transformational diakonia' can contribute in this process. Further reflection on the different attributes of religion in the development process and the distinctive role of FBOs in development, humanitarian aid and in peace-building processes, especially in multireligious contexts, is also necessary, with special attention for the role of trust. These processes and reflections may lead to a deepening of FBOs' understanding of development as well as with regard to their joint engagement in development and the strengthening and broadening of the concept of transformational development.

\section{Acknowledgements}

I would like to thank Prof. Ignatius Swart and Prof. Afe Adogame for the invitation to write this article and the reviewers for their valuable input. I also wish to thank the editorial team of HTS. 


\section{Competing interests}

The author declares that she has no financial or personal relationships which may have inappropriately influenced her in writing this article.

\section{References}

ACT Alliance, 2011, Shrinking political space for civil society action, ACT, Geneva.

ACT Alliance, 2012a, We all want a future: Addressing inequality in the Post-2015 Global Development Agenda, ACT, Geneva.

ACT Alliance, 2012b, Final document of the regional consultation for Latin America and the Caribbean, ACT, Montelimar.

ACT Alliance, 2013a, The changing development paradigm: An ACT Alliance Discussion Paper, ACT, Geneva.

ACT Alliance, 2013b, Our understanding of development, ACT, Geneva, viewed 7 August 2014, from http://www.actalliance.org/resources/policies-andguidelines/our-understanding-of-development/Our_Understanding_of_Dev ACTD-ACTA_ENGLISH_Jan2013.pdf

ACT Alliance, 2015, The role of faith-based organizations in humanitarian response: $A$ reflection on the unique role of FBOs in humanitarian crises, ACT, Geneva.

Amin, A., 2009 'Locating the social economy', in A. Amin (ed.), The social economy: International perspectives on economic solidarity, pp. 3-21, Zed Books, London.

Association of World Council of Churches Related Development Organisations in Europe (APRODEV), 2008, Rights-based development from a faith-based perspective viewed 8 , Rights-based development from a faith-based perspective, viewed 8 October 2015, from http://Www.ap

Association of World Council of Churches Related Development Organisations in Europe (APRODEV), 2012, Development and religion: A discussion Paper, viewed 8 January 2016, from http://www.aprodev.eu/files/about us reports/aprodev 8 January 2016, from http://Ww
developreligion_final_web.pdf

Brazil, Ministério de Desenvolvimento Social e Combate à Fome, 2007, Chamada Nutricional Quilombola 2006 - Resumo Executivo, Ministério de Desenvolvimento Social e Combate à Fome, Brasília.

Confédération européenne des ONG d'urgence et de développement (CONCORD) 2015, CONCORD Aid Watch 2015: Looking to the future, don't forget the past - Aid beyond 2015, viewed 8 January 2016, from http://www.concordeurope.org/ publications/item/download/474_c8b51e7c9e3308030351627e1f347609

Dash, A., 2014, 'Towards an epistemological foundation for social and solidarity economy', Occasional papers: Potential and limits of social and solidarity economy, vol. 3, pp. 1-23, UNRISD, viewed 10 October 2014, from http://www. unrisd.org/dash

Dutra, M.V.F. (ed.), 2011, Quilombolas rights: A study of the impact of ecumenical cooperation, Koinonia, Rio de Janeiro, viewed 20 July 2015, from http://www. koinonia.org.br/uploads/QUILOMBOLAS_RIGHTS.pdf

Economic Commission for Latin America and the Caribbean (ECLAC), 2010, Time for equality: Closing gaps, opening trails, ECLAC, Santiago.

Evans, P., 2002, 'Collective capabilities, culture, and Amartya Sen's development as freedom', Studies in Comparative International Development 37(2), 54-60. http:// dx.doi.org/10.1007/BF02686261

Joint Learning Initiative on Faith and Local Communities (JLIFLC), 2015, Building more effective partnership between public sector and faith groups, viewed 20 January 2016, from http://jliflc.com/wp-content/uploads/2015/06/NEWBuilding-moreeffective-partnerships-between-public-sector-and-faith-groups-1.pdf

Manzoni, M.L. \& Wolff, L.A., 2011, 'O Brasil e a cooperação internacional não governamental: Desafios de agências ecumênicas européias e suas entidades parceiras', Le Monde Diplomatique Brasil, pp. 7-8, viewed 10 January 2013, from http://www.abong.org.br/final/download/encartediplo.pdf
Nordstokke, K., (ed.), 2009, Diakonia in context: Transformation, reconciliation empowerment: An LWF contribution to the understanding and practice of diakonia, Lutheran World Federation, Geneva.

Nordstokke, K., 2014, 'Ecumenical diakonia: Responding to the signs of the times', The Ecumenical Review 66(3), 265-273. http://dx.doi.org/10.1111/erev.12104

Nussbaum, M., 2011, Creating capabilities, Cambridge University Press, Cambridge.

Organisation for Economic Co-operation and Development (OECD), 2011, The Busan partnership for effective development cooperation, viewed 3 July 2013, from http://www.oecd.org/dac/effectiveness/Busan\%20partnership.pdf

Ostrom, E., 2010, 'Beyond markets and states: Polycentric governance of complex economic systems', American Economic Review 100(3), 641-672. http://dx doi. org/10.1257/aer.100.3.641

Phiri, I.A. \& Kim, D., 2014, 'Called to be a diaconial community through a pilgrimage of justice and peace', The Ecumenical Review 66(3), 252-264. http://dx.doi. org/10.1111/erev.12103

Razeto, L., 1993, 'Economia de solidariedade e organização popular', in M. Gadotti \& F. Gutiérrez (eds.), Educação comunitária e economia popular, pp. 34-58, Cortez, São Paulo.

Reetz, H., 2013, Was Bewirkt die Förderung von Klein-Projekten bei Menschen in Selbsthilfeund Basisgruppen. Fallstudien in 4 Südamerikanischen Kleinprojekteprogrammen, BfdW, Berlin

Ruben, R., 2011, 'Can religion contribute to development? The road from "truth" to "trust"', Exchange 40, 225-234, viewed 8 October 2015, from http://www.ru.nl/ publish/pages/630027/exch_040_03_225-234.pdf

Sen, A., 1985, 'Well-being, agency and freedom: The Dewey lectures 1984', The Journal of Philosophy 82(4), 169-221. http://dx.doi.org/10.2307/2026184

Sen, A., 1988, On ethics and economics, Blackwell Publishing, Oxford.

Sen, A., 1999, Development as freedom, Anchor Books, New York.

Sen, A., 2009, The idea of justice, Harvard University Press, Cambridge.

Singer, P., 2000, 'Economia solidária: um modo de produção e distribuição', in P. Singer \& A. Souza (eds.), A economia solidária no Brasil: A autogestão como resposta ao desemprego, pp. 11-28, Contexto, São Paulo.

Statement on Ending of Extreme Poverty, signed at Washington, on 9 April 2015 Ending extreme poverty: A moral and spiritual imperative, 2015, viewed 8 October Ending extreme poverty: A moral and spiritual imperative, 2015, viewed 8 October poverty-a-moral-and-spiritual-imperative-1081333677.html

United Nations Development Programme (UNDP), 2012, Caribbean Human Development Report 2012: Human development and the shift to better citizen Development Report 2012:
security, UNDP, New York.

United Nations Development Programme - International Policy Centre for Inclusive Growth (UNDP-IPC-IG), 2010, 'South-South cooperation: The same old game or a new paradigm', Poverty in Focus No. 20.

World Council of Churches (WCC), 2012, Theological perspectives on diakonia in the 21st century, viewed 20 January 2016, from http://www.oikoumene.org/en/ resources/documents/wcc-programmes/unity-mission-evangelism-andspirituality/just-and-inclusive-communities/theological-perspectives-ondiakonia-in-21st-century

World Council of Churches (WCC), 2013, Statement on the way of just peace, viewed 20 January 2016, from http://www.oikoumene.org/en/resources/documents/ assembly/2013-busan/adopted-documents-statements/the-way-of-just-peace

Zeeland, A.J.W.M. van, 2014a, Economia solidária, diaconia e desenvolvimento transformador: Por mudanças significativas e duradouras, Oikos, São Leopoldo.

Zeeland, A.J.W.M. van, 2014b, 'The changing development context: A Latin American perspective', The Ecumenical Review 66(3), 313-323. http://dx.doi.org/10.1111/ erev.12108

Zeeland, A.J.W.M. van, 2014c, The interaction between popular economy socia movements and public policies: A case study of the waste pickers' movement Occasional papers: Potential and limits of social and solidarity economy, vol. 11 pp. 1-13, UNRISD, viewed 10 October 2014, from http://www.unrisd.org/ vanzeeland 